\title{
Evaluation of Treatment Applications and Antibiotic Resistance Rates for Community Acquired Urinary Tract Infections in Turkey and a Review of the Literature
}

\author{
Türkiye'de Toplum Kaynakıı Idrar Yolu Enfeksiyonlarında Tedavi Uygulamalarının ve \\ Antibiyotik Direnç Oranlarının Değerlendirilmesi ve Literatür Eşliğinde Gözden Geçirilmesi
}

Aşkın Eroğlu1' [iD] Elçin Akduman Alaşehir2

${ }^{1}$ Başkent University Faculty of Medicine, Department of Urology, Izmir, Turkiye

2 Maltepe University Faculty of Medicine, Department of Medical Microbiology, istanbul, Turkiye

What's known on the subject? and What does the study add?

In Turkiye, every day is used as empiric antibiotic resistance for urinary tract infection antibiotics urgently change our preferred and make more urine Culture.

\begin{abstract}
Objective: Increased extended-spectrum beta lactamase (ESBL) production is associated with higher rates of community-acquired strains in urinary tract infections (UTI) leading to an increase in the resistance rates, duration of treatment and costs. We aimed to investigate the resistance rates of ESBL-positive urine culture strains in our clinic, reviewed the literature and analysed antibiotics used in UTI treatment in outpatients in Turkiye. Materials and Methods: 2913 patients who were admitted to the outpatient clinics of Maltepe University Faculty of Medicine and Başkent University Faculty of Medicine were evaluated retrospectively. Data on prescribed antibiotics in outpatients with the diagnosis of UTI from all cities of Turkiye were collected through the Turkish Ministry of Health, Turkish Medicines and Medical Devices Agency.

Results: Out of 563 ESBL-positive (19.3\%) urine culture isolates, 450 (79.9\%) were Escherichia coli and 89 (15.8\%) were Klebsiella sp. Resistance rates were as follows: $98.8 \%$ to cefuroxime, $67.6 \%$ to ciprofloxacin, $12.5 \%$ to fosfomycin, $8.7 \%$ to amikacin, $1.4 \%$ to meropenem and $15 \%$ to nitrofurantoin. The most commonly prescribed antibiotics were ciprofloxacin (22.25\%), fosfomycin (21.10\%) and nitrofurantoin (12.82\%).

Conclusion: Our study suggests that the antibiotic resistance rates of most antibiotics prescribed for UTI in Turkiye are above the suggested rate of $10-20 \%$ to be used as empirical therapy. Updating and dissemination of guidelines for UTI in the light of antibiotic prescribing and resistance surveillance studies will contribute to the rational use of antibiotics in Turkiye.
\end{abstract}

Keywords: Community-acquired urinary tract infection, Empiric therapy, Extended spectrum beta lactamase

Öz

Amaç: Artan geniş spektrumlu beta laktamaz (ESBL) üretimi, idrar yolu enfeksiyonlarında (IYE) toplum kaynaklı suşların daha yüksek oranlarıyla ilişkilidir, bu da direnç oranlarında, tedavi süresinde ve maliyette bir artışa yol açar. Kliniğimizdeki ESBL pozitif idrar kültürü suşlarının direnç oranlarını araştırmayı, literatürü gözden geçirmeyi ve Türkiye'de ayaktan hastalarda IYE tedavisinde kullanılan antibiyotikleri analiz etmeyi amaçladık.

Gereç ve Yöntem: Maltepe Üniversitesi Tıp Fakültesi ve Başkent Üniversitesi Tıp Fakültesi poliklinikler'ine başvuran 2913 hasta retrospektif olarak incelendi. Türkiye'nin tüm illerinden idrar yolu enfeksiyonu tanısı alan ayaktan hastalarda reçete edilen antibiyotik verileri TC Sağlık Bakanlığı, Türkiye İlaç ve Tıbbi Cihaz Kurumu Reçeteleme Bilgileri ile toplandı.

Bulgular: Beş yüz altmış üç ESBL pozitif $(\% 19,3)$ idrar kültürü izolatından $450(\% 79,9)$ Escherichia coli ve $89(\% 15,8)$ Klebsiella sp. Direnç oranları sefuroksime $\% 98,8$, siprofloksasine $\% 67,6$, fosfomisine $\% 12,5$, amikasine $\% 8,7$, meropeneme $\% 1,4$ ve nitrofurantoine $\% 15$ idi. En sık reçete edilen antibiyotikler siprofloksasin $(\% 22,25)$, fosfomisin $(\% 21,10)$ ve nitrofurantoindir $(\% 12,82)$.

Correspondence: Aşkın Eroğlu MD, Başkent University Faculty of Medicine, Department of Urology, İzmir, Turkiye

Phone: +90 2322411032 E-mail: askineroglu@gmail.com ORCID-ID: orcid.org/0000-0003-2404-6209

Received: 31.03 .2020

Accepted: 03.04.2020

Cite this article as: Eroğlu A, Akduman Alaşehir E. Evaluation of Treatment Applications and Antibiotic Resistance Rates for Community Acquired Urinary Tract Infections in Turkey and a Review of the Literature. 2020;7(2):114-119.

๑Copyright 2020 by the Association of Urological Surgery / Journal of Urological Surgery published by Galenos Publishing House. 
Sonuç: Çalışmamız, Türkiye'de IYE için reçete edilen çoğu antibiyotiğin antibiyotik direnç oranlarının ampirik tedavi olarak kullanılmak üzere önerilen \%10-20 oranının üzerinde olduğunu göstermektedir. Antibiyotik reçeteleme ve direnç sürveyans çalışmaları ışı̆̆ında iYE kılavuzlarının güncellenmesi ve yaygınlaştırılması, Türkiye'de antibiyotiklerin akılcı kullanımına katkıda bulunacaktır.

Anahtar Kelimeler: Dirençli idrar yolu enfeksiyonu, Ampirik tedavi, Geniş spektrumlu beta laktamaz

\section{Introduction}

Urinary tract infections (UTIs), one of the most common infections in our country, are the reason of outpatient referral of more than 7 million patients with 2 million cases of cystitis in the United States, and 15\% of antibiotics are prescribed for UTIs (1). UTIs account for an overall annual cost of more than 1 billion dollars in the US (2). It has been reported that the annual cost of treating UTIs was 150 billion dollars in the world (3). To our knowledge, there are no studies reporting the annual cost of UTI in Turkiye.

The diagnosis and treatment of UTIs depend on a number of factors including patient-related risk factors, previous infections, previously isolated microorganisms and their resistance status (2). The most common cause of community-acquired UTIs is Escherichia coli, and the preferred antibiotics in empiric therapy are trimethoprim-sulfamethoxazole (TMP-SMX), nitrofurantoin monohydrate, fosfomycin trometamol, fluoroquinolones and beta lactam group antibiotics (4). Extended-spectrum beta lactamases (ESBLs) can hydrolyze third and fourth generation cephalosporins and monobactam, but they have no effect on cephamycin and carbapenems. ESBL is inhibited by clavulanic acid (sulbactam or tazobactam). The ESBL-encoding plasmids often lead to co-resistance against aminoglycosides and quinolones (5). It is noteworthy that ESBL production, which is important in terms of community health, is now highly prevalent in community-derived strains, and the increase in sulfonamide, aminoglycoside and fluoroquinolone resistance is also remarkable (6). Increased resistance rates lead to changes in the treatment regimen, prolongation of treatment time and increased cost.

Our aim in this study was to investigate the resistance patterns of ESBL-positive strains isolated in UTIs both in our laboratory and in different regions of Turkey and to evaluate antibiotics prescribed for UTI in outpatients in Turkey. The results of our study aimed at guiding the rational drug use in our country.

\section{Materials and Methods}

2913 patients, who were admitted to the outpatient clinics of Maltepe University Faculty of Medicine (istanbul) and Başkent University Training and Research Hospitals between 2010 and 2018 and had positive urine cultures, were evaluated retrospectively. Antibiotic susceptibility results of the same strain were excluded from the study. Only the first sample was included in the study. All procedures received approval from the Ethics Committee of Samsun Research and Training Hospital. Institutional review board approved the study with the protocol number TUEK 112-2018 GOKAEK/1-8. All methods were carried out in accordance with relevant guidelines and regulations.

Urine samples of $10 \mu \mathrm{L}$ were inoculated onto sheep blood agar and eosin methylene blue agar plate. After 18-24 hours incubation at $37{ }^{\circ} \mathrm{C}$, isolates with $\geq 10^{5} \mathrm{cfu} / \mathrm{mL}$ were evaluated as causative agents. The strains were identified by conventional methods, using the Api $20 \mathrm{E}$ (Bio-Mérieux, France) and VITEK (Bio-Mérieux, France) systems and antibiotic susceptibility was investigated by the Kirby-Bauer disc-diffusion method according to the criteria of the Clinical and Laboratory Standards Institute. The presence of ESBL was investigated by combination disc test using cefotaxime, ceftazidime and clavulanic acid-added combination discs of the same cephalosporins and with VITEK 2.0 (7).

Data on the preferred antibiotics in the outpatients treated with the diagnosis of UTIs in all cities of Turkey (2016 calendar year) was collected through the Turkish Ministry of Health, Turkish Medicines and Medical Devices Agency Prescription Information System and analyzed.

\section{Statistics Analysis}

Statistical analysis was performed using Google Sheets. Descriptive statistics are presented with mean, standard deviation, frequency and percentage values.

\section{Results}

In our study, a total of 563 ESBL-positive (19.3\%) urine culture isolates were identified and the antibiotic susceptibility test results were evaluated. Of these isolates, $450(79.9 \%)$ were $E$. coli, 89 (15.8\%) were K. pneumoniae/oxytoca, 5 (0.9\%) were Proteus sp. and $19(3.4 \%)$ were identified as other members of the Enterobacteriaceae family.

The resistance rates of ESBL-positive isolates are shown in Table1. The resistance rates were 100\% for ampicillin, 98.8\% for cefuroxime, $67.6 \%$ for ciprofloxacin, $12.5 \%$ for fosfomycin, $8.7 \%$ for amikacin, 1.4\% for meropenem and 15\% for nitrofurantoine.

The resistance rates of ESBL-positive $E$. coli strains are given in Table 2. The resistance rates were 100\% for ampicillin, $98.8 \%$ for 
cefuroxime, $69.9 \%$ for ciprofloxacin, $8.3 \%$ for amikacin, $14.3 \%$ for fosfomycin, $8.7 \%$ for nitrofurantoin, $0.6 \%$ for meropenem and $0.5 \%$ for imipenem.

The resistance rates of ESBL-positive K. pneumoniae/oxytoca strains against ampicillin are given in Table 3 . The highest resistance was 100\% for ampicillin, 100\% for cefazolin, 98.4\% for cefuroxime, $98.4 \%$ for ceftriaxone, $98.4 \%$ for cefotaxime, $12.1 \%$ for amikacin, $4.9 \%$ for meropenem, and 3.3\% for imipenem.

Of the total of $3.517,172$ prescriptions were written with the diagnosis of UTI in Turkiye in 2016. 80.0\% of these prescriptions were written by family medicine specialists. The most commonly prescribed antibiotics, prescription rates and our resistance rates for the respective antibiotics are shown in Table 4. The total cost of these antibiotics prescribed for outpatients was 51.859.247,82 Turkish Lira (TL) and the cost per prescription was calculated to be $14.74 \mathrm{TL}$. The provinces with the highest

\begin{tabular}{|c|c|}
\hline $\begin{array}{l}\text { Resistance } \\
\text { rate }\end{array}$ & Antibiotics and resistance rates \\
\hline$>\mathbf{8 0} \%$ & $\begin{array}{l}\text { Ampicillin (100\%), Cephazolin (98.9\%), Cefuroxime } \\
(98.8 \%), \text { Cefotaxime }(98.8 \%), \text { Ceftriaxone }(98.3 \%), \\
\text { Cefepime }(92.0 \%), \text { Ceftazidime }(83.0 \%) \text {, Ampicillin/ } \\
\text { Sulbactam (89.0\%), Amoxicillin/Clavulanic Acid } \\
(86.2 \%)\end{array}$ \\
\hline $60 \%-80 \%$ & $\begin{array}{l}\text { Trimethoprim Sulfamethoxazole }(73.1 \%), \\
\text { Ciprofloxacin }(67.6 \%), \text { Levofloxacin }(64.1 \%), \\
\text { Cefoxitin }(58.5 \%)\end{array}$ \\
\hline $40 \%-60 \%$ & Gentamicin (42.0\%) \\
\hline $20 \%-40 \%$ & Piperacillin/Tazobactam (30.4\%) \\
\hline$<20 \%$ & $\begin{array}{l}\text { Netilmicin }(18.8 \%), \text { Nitrofurantoin }(15.0 \%), \\
\text { Amikacin }(8.7 \%), \text { Ertapenem }(3.4 \%), \text { Meropenem } \\
(1.4 \%), \text { Imipenem }(0.8 \%)\end{array}$ \\
\hline
\end{tabular}

Table 2. Antibiotic resistance rates of extended-spectrum beta lactamase-positive $E$. coli isolates

\begin{tabular}{|l|l|}
\hline Resistance rate & Antibiotics and resistance rates \\
\hline$>80 \%$ & $\begin{array}{l}\text { Ampicillin (100.0\%), Cefuroxime (98.8\%), } \\
\text { Cefotaxime (98.9\%), Cefazolin (98.5\%), } \\
\text { Ceftriaxone (98.3\%), Cefepime (91.2\%), } \\
\text { Ampicillin/Sulbactam (89.2\%), Ceftazidime } \\
(88.4 \%), \text { Amoxicillin/Clavulanic Acid (86.4\%) }\end{array}$ \\
\hline $60 \%-80 \%$ & $\begin{array}{l}\text { Trimethoprim Sulfamethoxazole (70.7\%), } \\
\text { Ciprofloxacin (69.9\%), Levofloxacin (69.3\%), } \\
\text { Cefoxitin (60.0\%) }\end{array}$ \\
\hline $40 \%-60 \%$ & Gentamicin (41.8\%) \\
\hline $20 \%-40 \%$ & Piperacillin/Tazobactam (27.2\%) \\
\hline$<20 \%$ & $\begin{array}{l}\text { Netilmicin (19.2\%), Fosfomycin (14.3\%), } \\
\text { Nitrofurantoin (8.7\%), Amikacin (8.3\%), } \\
\text { Ertapenem (2.1\%), Meropenem (0.6\%), } \\
\text { Imipenem (0.5\%) }\end{array}$ \\
\hline
\end{tabular}

vvnumber of prescriptions were İstanbul (14.0\%), İzmir (4.8\%), Ankara (4.2\%), Balıkesir (4.1\%) and Bursa (4.0\%).

\section{Discussion}

Patients with UTIs constitute $17.8 \%$ of patients admitted to outpatient health services in Turkiye every year and account for significant health costs (8). In our study, the most commonly prescribed antibiotics for the diagnosis of UTI in Turkiye and their resistance rates of our clinic were examined and they were found to be $67.6 \%$ for ciprofloxacin, 12.5\% for fosfomycin, 15\% for nitrofurantoin, 100\% for ampicillin and 98.8\% for cefuroxime, respectively. The data we presented in our study showed that the treatment of UTI in Turkiye in 2016 incurred cost in excess of 50 million TL.

E. coli is the most common type I $\mathrm{n}$ both the hospital- and community-acquired UTIs, and the incidence rate in all UTIs is reported to be $55-95 \%$ (9). In our study, E. coli constituted $79.9 \%$ of UTIs and this data was compatible with the literature.

ESBL-positive E. coli detection in uncomplicated UTIs indicates that these strains are no longer only in the hospital environment but are spreading and must be taken into account in the selection of treatment in primary care $(10,11,12,13)$.

In our study, the ESBL rate was found to be $19.3 \%$. This rate is consistent with the literature. A meta-analysis from Turkey that examined the results of 101 studies published between the years of 1996 and 2012 detected that in outpatients treated due to UTIs, the rates of strains producing ESBL was below 20\% (14). In the same study, it was reported that ESBL rates increased in the period of 2008-2012 compared to the 2002-2007 period. In the SMART study presenting data on the prevalence of ESBL in Enterobacteriaceae isolates in UTI from 2009 to 2011, a high ESBL rate was reported in both Asia and the Middle East, and a significant increase in ESBL rate was reported over the years. The average prevalence of ESBL-positive pathogens causing

\begin{tabular}{|c|c|}
\hline Resistance & Antibiotic and resistance rates \\
\hline$>80 \%$ & $\begin{array}{l}\text { Cefazolin (100.0\%), Ampicillin (100.0\%), } \\
\text { Cefuroxime (98.4\%), Ceftriaxone (98.4\%), } \\
\text { Cefotaxime (98.4\%), Cefepime (96.7\%), } \\
\text { Ceftazidime (96.8\%), Ampicillin/Sulbactam } \\
\text { (87.5), Trimethoprim -Sulfamethoxazole } \\
\text { (88.5\%), Amoxicillin/Clavulanic Acid (84.3\%) }\end{array}$ \\
\hline $60 \%-80 \%$ & Nitrofurantoin (62.7\%) \\
\hline $40 \%-60 \%$ & $\begin{array}{l}\text { Piperacillin Tazobactam (48.4\%), Ciprofloxacin } \\
(49.0 \%), \text { Cefoxitin }(46.6 \%), \text { Gentamicin } \\
(41.3 \%)\end{array}$ \\
\hline $20 \%-40 \%$ & Levofloxacin (31.7\%) \\
\hline$<20 \%$ & $\begin{array}{l}\text { Netilmicin (16.4\%), Amikacin (12.1\%), } \\
\text { Ertapenem (9.5\%), Meropenem (4.9\%), } \\
\text { Imipenem (3.3\%) }\end{array}$ \\
\hline
\end{tabular}




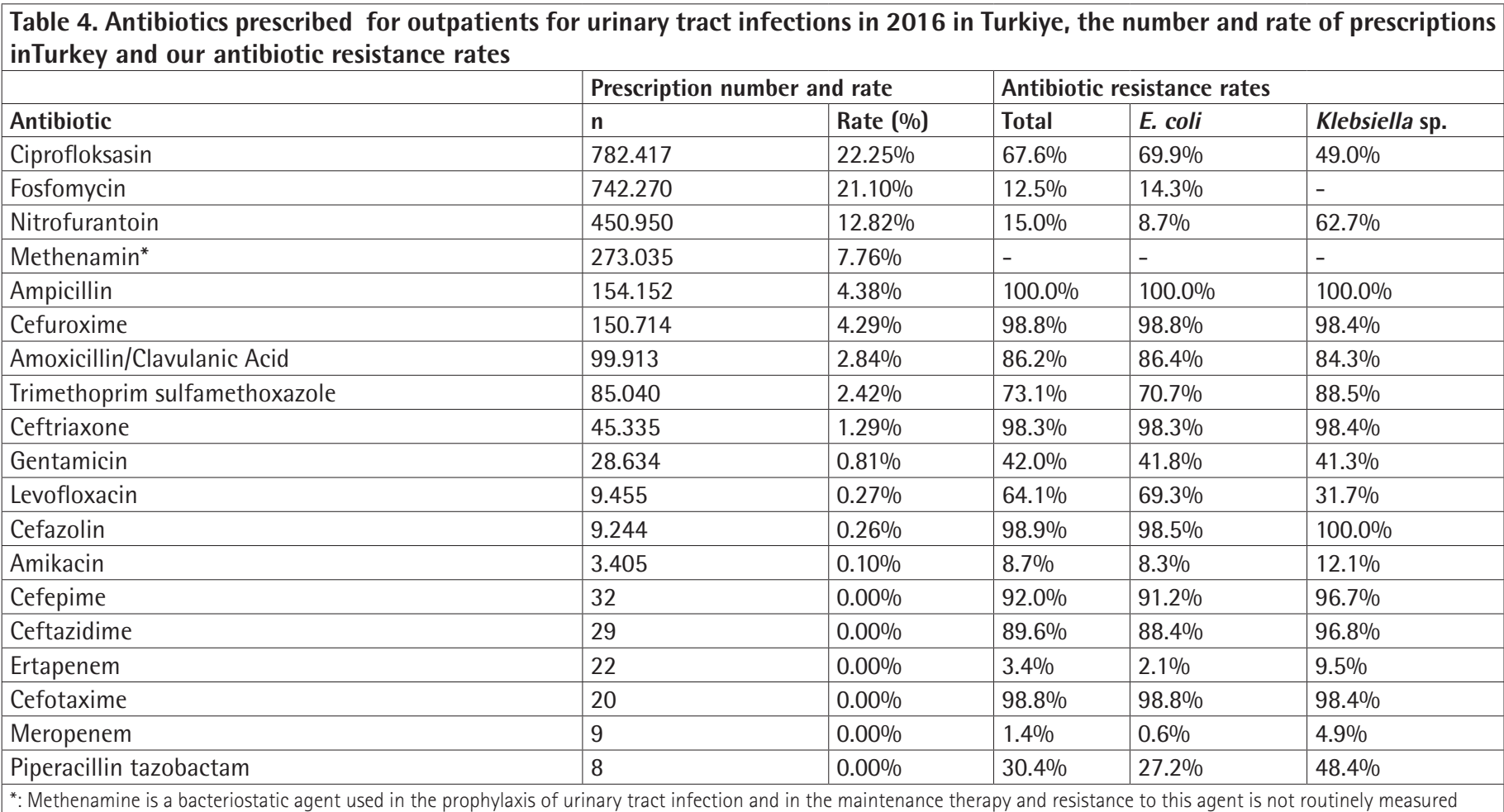

UTI in Europe has been reported to be 20\% (15). Forming a part of the SMART study, uncomplicated UTI data belonging to Turkiye (2011-2012); the most prevalent Gram-negative bacteria associated with uncomplicated UTI were E. coli (73.9\%). The rate of ESBL-positive E.coli was 38.2\% and ESBL-positive K. pneumoniae was $42 \%$ and it was stated that these rates were higher than in the other participating regions. Decrease in susceptibility to fluoroquinolone, ampicillin-sulbactam and cephalosporins was also remarkable in terms of limiting the choice of empiric treatment (16). Similarly, high rates of resistance to ampicillin, amoxicillin/clavulanic acid (AMC) and cephalosporins were found in our study. The high rate of prescription of these antibiotics for UTI indicates improper use of these drugs.

In a multicenter study from Belgium, Germany and Spain, E.coli strains isolated from community-acquired UTIs were generally resistant to AMC, fluoroquinolones and TMP-SMX, but the resistance to fosfomycin and nitrofurantoin was rare. Oral cephalosporins were found to be effective except for ESBLpositive strains. Lower resistance rates were found in Belgium compared to Germany and Spain (17). Thus, the resistance epidemiology differs between patient groups and countries due to the use of antimicrobials and/or the spread of resistant clones $(18,19)$.

Antimicrobial resistance rates play an important role in the selection of an antimicrobial agent to be used empirically for treatment. For this reason, it is important to conduct studies based on country, region and even hospital. It is recommended that the rate of resistance to the empiric agent should not exceed 10-20\% (9). The Infectious Diseases Society of America recommends the use of nitrofurantoin, fosfomycin or TMP-SMX for uncomplicated cystitis in women, and fluoroquinolone or beta-lactam in acute pyelonephritis if local resistance rates do not exceed 20\% (4). When we look at the resistance rates of these antibiotics in our current series, we can see that the rates of resistance to nitrofurantoin and TMP-SMX for E. coli are below 20\% and they are the second and third most common antibiotics. On the other hand, the rate of resistance to the most prescribed antibiotic ciprofloxacin in Turkey was found to be $67.6 \%$ (only $69.9 \%$ for E.coli). Aktar et al. (20) found that the rate of resistance to ciprofloxacin was 23.9\% for ESBL-negative E. coli and $61.5 \%$ for ESBL-positive strains and in addition, in different studies from Turkiye, the rate of ESBL-positive $E$. coli resistance to ciprofloxacin has been reported to be 55.6\%-96\%. In 2012, Mollahaliloğlu et al. (21) analyzed antibiotics prescribed in Turkey's 10 provinces (Eskişehir, Denizli, Niğde, Nevşehir, Bartın, Karabük, Gümüşhane, Bayburt, Çankırı ve Kırşehir) and found that one of the fifth most common diagnoses subject to antibiotic prescription was UTI. In the same study, it was reported that the most frequently prescribed antibiotics for UTI were ciprofloxacin (23.3\%) and levofloxacin (20.3\%). Considering our data, the fact that ciprofloxacin is still the most commonly prescribed antibiotic may be associated with a high rate of resistance.

In a prospective study including 429 patients conducted by Aypak et al. (22) in 2009, it was reported that the most frequently 
prescribed antibiotics were fluoroquinolones (77\%), TMP-SMX (10.7\%), fosfomycin (9.2\%) and nitrofurantoin (2.1\%). In our country, when we look at the first 10 antimicrobials prescribed for UTI in the outpatient clinics (ciprofloxacin, fosfomycin, nitrofurantoin, methenamine, ampicillin, cefuroxime, AMC, TMP-SMX, ceftriaxone and gentamicin), these agents account for almost $80 \%$ of the prescriptions and just the rate of resistance to fosfomycin and nitrofurantoin was less than $20 \%$. The rate of resistance to less prescribed antibiotics, such as amikacin, meropenem, piperacillin-tazobactam and chloramphenicol, is below $20 \%$ but these agents do not have enteral form.

Güneysel et al. (23) found high rates of resistance to cefpodoxime, AMC and ciprofloxacin for E.coli, especially in patients over 50 years of age and and suggested that TMP-SMX should be excluded from empiric treatment for uncomplicated UTI due to high resistance rate. In addition, it was emphasized that fosfomycin was a good option in all age groups.

Klebsiella sp. pathogens other than E. coli are more resistant to many antibiotics such as AMC, cephalosporin, nitrofurantoin and amikacin (24). The high rate of resistance to nitrofurantoin in Klebsiella $s p$. isolates found in our study is also consistent with this information. This shows that it is not always appropriate for empiric treatment in non-E.coli strains. Urine culture and antibiotic susceptibility tests are very important in the treatment of these patients (24).

The data we presented in our study revealed that $80.0 \%$ of the prescriptions for the outpatient treatment of UTI was written by family physicians in Turkiye. When this data is taken into account, the need for a training program can be seen obviously and we assume that the first step should be family physicians. TMP-SMX has been recommended as the first choice empiric treatment for uncomplicated UTI in Turkiye $(25,26)$. However, the rate of prescribing of this antibiotic was only $2.42 \%$. The rate of TMP-SMX resistance was found to be $73.1 \%$ for all strains and 70.7\% for E. coli, and it is not appropriate to use for empiric therapy and the empiric treatment suggestions in our country should be changed.

Our study has some limitations. No distinction was made between child and adult patients in the calculation of antibiotic resistance rates and costs. In addition, it is not known whether antibiotics were prescribed for empiric treatment or according to culture-antibiogram test results. However, high resistance rates suggested that they were used for empiric treatment. The fact that the data on antibiotic resistance rates presented in this study was from two provinces and two centers can be considered as another limitation. However, although we have not statistically tested these rates, the results can be generalized as these two provinces are the largest in Turkey also where the most prescriptions for UTI are written.

\section{Conclusion}

Our study suggests that the antibiotic resistance rates of most prescribed antibiotics to be used as empiric therapy for UTI in Turkiye are $10-20 \%$ higher than estimated. In the light of this data, one can say that there is an improper use of commonly prescribed antibiotics for UTI. It is also recommended that the resistance rates of each region or even every hospital should be analysed and ESBL-positive rates should be calculated in order to choose the antibiotic to be used in empiric treatment. High rates of resistance to quinolones, cephalosporins, AMC and TMP-SXT indicate the importance of drug selection according to the results of antibiotic susceptibility test, especially in ESBLpositive isolates (27).

As a result; such pharmacoepidemiological studies have led to the emergence of increased antibiotic resistance rates due to irrational use of antibiotics. Pre-treatment culture, agentspecific treatment planning, and good evaluation of regionspecific resistance profiles in the selection of empiric treatment are the basis of rational antibiotic use. Antibiotic prescribing and resistance surveillance studies will lead to updating of guidelines for UTI treatment and expanding their use will contribute to the rational use of antibiotics in Turkiye.

\section{Acknowledgments}

We would like to thank due to her contribution to the collection of the data which constitute the source of this article, industrial engineer Esma Kadi, Rational DrugUse Department for Monitoring and Evaluation, and Assoc. Dr. David T. Thomas for evaluation of thedata.

\section{Ethics}

Ethics Committee Approval: The study were approved by the Samsun Research Hospital of Local Ethics Committee (Protocol number: TUEK 112-2018 GOKAEK/1-8).

Informed Consent: Consent form was filled out by all participants.

Peer-review: Internally peer-reviewed.

\section{Authorship Contributions}

Surgical and Medical Practices: A.E., Concept: A.E., E.A.A., Design: A.E., Data Collection or Processing: A.E., E.A.A., Analysis or Interpretation: A.E., E.A.A., Literature Search: A.E., E.A.A., Writing: A.E., E.A.A.

Conflict of Interest: No conflict of interest was declared by the authors.

Financial Disclosure: The authors declared that this study received no financial support. 


\section{References}

1. Bonkat $G$, Pickard $R$, Bartoletti $R$, Bruyère $F$, Geerlings $S E$, Wagenlehner F, B. Wullt. Guidelines Associates: T. Cai , B. Köves, A. Pilatz, B. Pradere, R. Veeratterapillay (2017) EAU Guidelines on urological infections.EAU Guidelines, Edn.published as the $32^{\text {nd }}$ EAU Annual Meeting, London, EAoUGOffice, Editor.

2. Salatoğlu N, Approach to Infections of Community-Based Urinary Tract. Practical Approaches to Community Acquired Infections Symposium Sequence 2019;61:139-150 (Article inTurkish).

3. Kadanalı A. Urinary system infections EAJM 2006;38:119-123 (Article in Turkish).

4. Gupta K, Hooton TM, Naber KG, Wullt B, Colgan R, Miller LG, Moran GJ, Nicolle $L E$, Raz R, Schaeffer AJ, Soper DE. International clinical practice guidelines for the treatment of acute uncomplicated cystitis and pyelonephritis in women: a 2010 update by the Infectious Diseases Society of America and the European Society for Microbiology and Infectious Diseases. Clin Infect Dis 2011;52:e103-e120.

5. Mazzariol A, Bazaj A, Cornaglia G. Multi-drug-resistant Gram-negative bacteria causing urinary tract infections: a review. J Chemother 2017;29:29.

6. Zowawi HM, Harris PNA, Roberts MJ, Tambyah PA, Schembri MA,Pezzani MD, Williamson DA, Paterson DL, The emerging threat of multidrugresistant Gram-negative bacteria in urology. Nat Rev Urol 2015;12:570584.

7. CLSI (2013). Performance Standards for Antimicrobial Susceptibility Testing: Fifteenth Informational Supplement. CLSI Document M100:S23 Wayne, PA: Clinical and Laboratory StandardsInstitute.

8. Arslan H. Uncomplicated Urinary Tract Infections: Do the Guidelines Highlight Our Desicion? ANKEM Derg 2012;26:158-162.

9. Yılmaz N, Ağuş N, Bayram A, Şamlıŏlu P, Şirin MC, Derici YK, Hancı SY. Antimicrobial susceptibilities of Escherichia coli isolates as agents of community- acquired urinary tract infection (2008-2014). Turk J Urol 2016;42:32-36.

10. Pitout JDD, Laupland KB. Extended-spectrum beta-lactamase-producing Enterobacteriaceae: an emerging public-health concern. Lancet Infect Dis 2008;8:159-166.

11. Hertz FB, Nielsen JB, Schønning K, Littauer P, Knudsen JD, Anders LO, Niels FM. Population structure of drug-susceptible,-resistant and ESBLproducing Escherichia coli from community-acquired urinary tract. BMC Microbiol 2016;16:63.

12. Prakash V, Lewis JS, Herrera ML,Wickes BL, Jorgensen JH. Oraland parenteral therapeutic options for outpatient urinary infections caused by enterobacteriaceae producing CTX-M extended-spectrum betalactamases. Antimicrob Agents Chemother 2009;53:1278-1280.

13. Córdoba G, Holm A, Hansen F, Hammerum AM, Bjerrum L. Prevalenceof antimicrobial resistant Escherichia coli from patients with suspected urinary tract infection in primary care, Denmark. BMC Infect Dis 201;17:670.

14. Aykan ŞB, Çiftci ï. Antibiotic Resistance Patterns of Escherichia coli Strains Isolated from Urine Cultures in Turkey: A Meta-Analysis. Mikrobiyol Bul 2013;47:603-618 (Article inTurkish).
15. Morrissey I, Hackel M, Badal R, Bouchillon S, Hawser S, Biedenbach D. A Review of Ten Years of the Study for Monitoring Antimicrobial Resistance Trends (SMART) from 2002 to 2011. Pharmaceuticals 2013;6:1335-1346.

16. Koksal I, Yilmaz G, Unal S, Zarakolu P, Korten V, Mulazimoglu L,Tabak F, Mete B, Oguz VA, Gulay Z, Alp E, Badal R, Lob S. Epidemiology and susceptibility of pathogens from SMART 2011-12 Turkey: evaluation of hospital-acquired versus community-acquired urinary tract infections and ICU- versus non-ICU- associated intra-abdominal infections. J Antimicrob Chemother 72017;2:1364-1372.

17. Kresken M, Körber-Irrgang B, Biedenbach DJ, Batista N, Besard V, Cantón R, Garcia-CastilloM, Kalka-Moll W, Pascual A, Schwarz R, VanMeensel $B$, Wisplinghoff $H$, SeifertHet. Comparative in vitro activity of foralanti microbial agents against Enterobacteriaceae from patients with community-acquiredurinary tract infections in three European countries. Clin Microbiol Infect 2016;22:63.e1-e63.e5.

18. Ahmed NH, Hussain T, Biswal I. Comparison of etiological agents and resistance patterns of the pathogens causing community acquired and hospital acquired urinary tract infections. J Glob Infect Dis 2014;6:135136.

19. European Centre for Disease Prevention and Control. Surveillance of antimicrobial consumption in Europe. Stockholm: ECDC 2014.

20. Aktar GS, Ayaydın Z, Onur AR, Vural DG, Temiz H. Resistance Rates Against Various Antimicrobials in Escherichia Coli Strains Isolated from Urine Samples. Kocaeli Med J 2018;7:8-13 (Article inTurkish).

21. Mollahaliloğlu $S$, Alkan $A$, Dönertaş $B$, Özgülcü $S$, Dilmen U, Akıcı A. The evaluation of antibiotics written by physicians on single infection diagnosis prescriptions. Marmara Pharmaceutical Journal 2012;16:206212 (Article in Turkish).

22. Aypak C, Altunsoy A, Düzgün N. Empiric antibiotic therapy in acute uncomplicated urinary tract infections and fluoroquinolone resistance: a prospective observational study. Ann Clin Microbiol Antimicrob 2009;8:27.

23. Guneysel O, Suman E, Ozturk TC. Trimethoprim-Sulfamethoxazole Resistance And Fosfomycin Susceptibility Rates In Uncomplicated Urinary Tract Infections: Time To Change The Antimicrobial Preferences. Acta Clin Croat 2016;55:49-57.

24. Alberici $I$, Bayazit $A K$, Drozdz $D$, Emre $S$, Fischbach $M$, Harambat J,Jankauskiene A, Litwin M, Mir S, Morello W, Peco-Antic A, Sallay $P$, Sever L, Simonetti GD, Szczesniak P, Teixeira A, Vidal E, Wuehl E, Mehls O, Weber LT, Schaefer F, Montini G \{ESCAPE Study Group\}; \{PREDICT Trial\}. Pathogens causing urinary tract infections in infants: a European overview by the ESCAPE study group. Eur J Pediatr 2015;174:783-790.

25. Selçuk EB, Ak M, Karataş M. Approachto Dysuriain Primary Care. Turkiye Klinikleri J Fam Med-Special Topics 2012;3:1-4 (Article inTurkish).

26. Gönen $\mathrm{I}$, Akçam FZ, Yaylı G. Approach to common urinary infections in women. STED 2014;134:128-130 (Article in Turkish).

27. Çelikbilek N, Gözalan A, Özdem B, Kirca F, Açikgöz ZC. Extended-spectrum beta- lactamase production by

28. Enterobacteriaceae isolates from urinecultures of outpatients: results of a 7-year follow-up. Mikrobiyol Bul 2015;49:259-265 (Article in Turkish). 